\title{
Influence of bedrock mineral composition on microbial diversity in a subglacial environment
}

\section{Authors: Andrew C. Mitchell, Melissa J. Lafrenière, Mark L. Skidmore, and Eric S. Boyd}

NOTICE: This is a postprint of an article that originally appeared in Geology on June 2013.

DOI\#10.1130/g34194.1.

Mitchell AC, Lafrenière MJ, Skidmore ML, Boyd ES, "Influence of bedrock mineral composition on microbial diversity in a subglacial environment," Geology August 2013 41:855-858. 


\section{Influence of bedrock mineral composition on microbial diversity in a subglacial environment}

\section{Andrew C. Mitchell ${ }^{1,2}$, Melissa J. Lafrenière ${ }^{3}$, Mark L. Skidmore ${ }^{4}$, and Eric S. Boyd $^{5}$}

${ }_{1}$ Institute of Geography and Earth Sciences, Aberystwyth University, Aberystwyth, SY23 3DB, UK

${ }^{2}$ Center for Biofi Im Engineering, Montana State University, Bozeman, Montana 59717, USA

${ }^{3}$ Department of Geography, Queen's University, Kingston, Ontario K7L 3N6, Canada

${ }^{4}$ Department of Earth Sciences, Montana State University, Bozeman, Montana 59717, USA

${ }^{5}$ Department of Chemistry and Biochemistry, Montana State University, Bozeman, Montana 59717, USA

\section{ABSTRACT}

Microorganisms in subglacial environments drive the chemical weathering of bedrock; however, the infl uence of bedrock mineralogy on the composition and activity of microbial assemblages in such environments is poorly understood. Here, using a combination of in situ mineral incubation and DNA fi ngerprinting techniques, we demonstrate that pyrite is the dominant mineralogical control on subglacial bacterial community structure and composi-tion. In addition, we show that the abundance of Fe in the incubated minerals influences the development of mineral-associated biomass. The ubiquitous nature of pyrite in many common bedrock types and high $\mathrm{SO}_{4}{ }^{2-}$ concentrations in most glacial meltwaters suggest that pyrite may be a dominant lithogenic control on microbial communities in many subglacial systems. Mineral-based energy may therefore serve a fundamental role in sustaining subglacial microbial populations and enabling their persistence over glacial-interglacial time scales.

\section{INTRODUCTION}

Terrestrial ice masses currently cover $\sim 15 \times$ $10^{6} \mathrm{~km}^{2}, \sim 10 \%$ of Earth's land surface. The presence of viable microbes in terrestrial ice, subglacial sediments, and proglacial meltwaters has been demonstrated (Christner, 2002; Sharp et al., 1999; Skidmore et al., 2000, 2005) and ex situ (Boyd et al., 2011; Christner, 2002) and in situ (Boyd et al., 2010; Hamilton et al., 2013) evidence of microbial activities has been pre-sented. The lack of light energy capable of driv-ing photosynthesis in subglacial environments suggests that energy for cellular synthesis and the maintenance of microorganisms is supplied from chemical energy (chemosynthesis), likely derived from weathering of the local bedrock (e.g., minerals) (Luttge et al., 2005; Shock, 2009). Numerous lines of evidence suggest that many geochemical processes, including mineral weathering and redox transformations in subglacial environments, are driven by microorgan-isms (Boyd et al., 2011; Hamilton et al., 2013; Montross et al., 2013; Skidmore et al., 2005; Wadham et al., 2004; Wynn et al., 2007). Hydro-logical regimes (Tranter et al., 2005), nutrient availability, and redox conditions (Wadham et al., 2004; Wynn et al., 2007) have been shown to affect the function of microorganisms in sub-glacial environments. However, the influence of bedrock mineralogy on the structure, composi-tion, and activity of microbial assemblages in subglacial systems remains poorly understood despite its potential importance over a signifi -cant portion of Earth's surface both today and on glacialinterglacial time scales.

The importance of pyrite $\left(\mathrm{FeS}_{2}\right)$ oxidation as a dominant geochemical process in subglacial environments has been documented (Bottrell and Tranter, 2002; Brown, 2002; Tranter et al., 2002), and evidence suggests that this process is microbially mediated (Montross et al., 2013; Skidmore et al., 2005; Wadham et al., 2004). Sulfate is the second-most dominant anion (after bicarbonate) in most proglacial and subglacial meltwaters from alpine, arctic, and antarctic environments (Brown, 2002), and concentra-tions of $\mathrm{SO}_{4}{ }^{2-}$ are always signifi cantly enriched relative to possible input waters (e.g., icemelt or snowmelt), indicating a lithogenic source. In addition to $\mathrm{SO}_{4}{ }^{2-}$, other products of pyrite weath-ering are often ubiquitous in glacial meltwaters and sediments (Mitchell et al., 2001), including nanoparticles of Fe-oxyhydroxides (Raiswell et al., 2009). Surveys of subglacial microbial com-munity 16S rRNA transcripts (Hamilton et al., 2013) and genes (Lanoil et al., 2009; Skidmore et al., 2005) often yield sequences that are closely affi liated with organisms that actively metabo-lize Fe, S, and/or FeS minerals. Therefore, while geochemical and microbiological evidence suggests that $\mathrm{Fe}$ and $\mathrm{S}$ cycling are important in subglacial systems, the extent to which lithology and mineralogy shape community structure, composition, and activity is unknown. Here we employ a method to isolate the influence of mineralogy on the composition and structure of microbial communities in the subglacial envi-ronment at Robertson Glacier (RG), Alberta, Canada $\left(115^{\circ} 20^{\prime} \mathrm{W}, 50^{\circ} 44^{\prime} \mathrm{N}\right.$; Item DR1 and Fig. DR1a in the GSA Data Repository ${ }^{1}$ ). This approach employs coupon samplers composed of capped stainless-steel mesh cylinders (Item DR1; Fig. DR1b) that compartmentalize differ-ent minerals during in situ incubation (Boyd et al., 2007) in the glacial outfl ow channel of $R G \sim \mathbf{1 0} \mathrm{m}$ downstream of the glacier terminus, in order to assess the infl uence of mineralogy on the structure, composition, and abundance of the microbial community.

\section{MATERIALS AND METHODS}

Combustion-sterilized rocks and minerals (1.4-1.7 $\mathrm{mm}$ diameter) were incubated in the glacial meltwater stream at RG (western drainage) for 7 months over winter in order to promote colonization of mineral substrata contained in presterilized coupon samplers by microorgan-isms that originated from the subglacial system (Item DR1; Fig. DR1b). The close proximity of the coupons to the glacier and the subgla-cial source for the waters passing through the coupons provide confi dence that the microbial colonization that occurred refl ects subglacial microbial diversity. The selection of minerals, derived from mineral collections and chemically characterized by energy-dispersive $X$-ray spectroscopy (EDS) and X-ray diffraction (XRD) (Item DR1), included those that could serve as electron donors or acceptors Ipyrite, $\left(\mathrm{Fe}^{2+}\right.$, $\left.\mathrm{S}^{-}\right)$, hematite and magnetite $\left(\mathrm{Fe}^{3+}\right)$, and olivine $\left(\mathrm{Fe}^{2+}\right) \quad(90 \%$ forsterite $+10 \%$ fayalite; ${ }_{{ }_{0}}{ }_{90} \mathrm{Fa}_{10}=\mathrm{Mg}_{1 .} \mathrm{Fe}_{02} \mathrm{SiO}_{4} \cdot \mathrm{Fe}^{2+}=75,000 \pm$ 1425 ppm); Item DR1; Tablè DR1]. Minerals that offered no obvious metabolic substrate [quartz $\left(\mathrm{SiO}_{2}\right)$, cal-cite $\left.\left(\mathrm{CaCO}_{3}\right)\right]$ but were abundant in catchment bedrock (Table DR1; Sharp et al., 2002) were also included. In addition, we included repre-sentative rock from the RG catchment (dark shale containing quartz, microcline, calcite, and pyrite) that was prepared in the same way as the pure mineral phases. RG rock contained $9800 \pm 764$ ppm $\mathrm{Fe}^{2+}$ and $3000 \pm 360 \mathrm{ppm} \mathrm{S}$, and assuming all $\mathrm{S}$ came from pyrite, an estimated pyrite content of $0.56 \mathrm{wt} \%$ (Table DR1). Sub-glacial (RG water) and supraglacial meltwaters were collected aseptically and fi ltered through sterilized fi Iter apparatus with $0.22 \mu \mathrm{m}$ pore size polyvinylidene difl uoride membrane at the time of coupon deployment to compare the native

\footnotetext{
1GSA Data Repository item 2013238, Item DR1 (supplemental methods), and Item DR2 (extended results, including Figure DR1 and Tables DR1DR5), is available online at www.geosociety.org/ pubs/ft2013.htm, or on request from editing@geosociety.org or Documents Secretary, GSA, P.O. Box 9140, Boulder, CO 80301, USA.
} 
community with that that developed on the coupon minerals. Fine-grained subglacial sediment was also collected aseptically (RG sediment) from the site of coupon deployment at the time the coupon was retrieved. All mineral and sediment samples were immediately flash frozen on site using dry ice (Item DR1).

Coupon minerals, subglacial sediments (RG sediment), and filters with subglacial suspended sediments and planktonic (e.g., suspended) cells (RG water) were subjected to community DNA extraction, polymerase chain reaction amplification of bacterial 16S rRNA genes and terminal restriction fragment length polymorphism (TRFLP) (Item DR1). Distinct TRFs were considered to be unique operational taxonomic units and were the units by which individual phylotypes were demarcated. Comparison of TRFLP profiles was performed using the Bray-Curtis index, which represents an abundance weighted metric describing the similarity of communities (Item DR1). Clone library construction was also performed on pyrite- and RG sediment-associated communities following Boyd et al. (2007) to determine similarity with known microorganisms (Item DR1). Filtered waters $(0.22 \mu \mathrm{m})$ were immediately measured for $\mathrm{pH}$ and electrical conductivity in the field, and were analyzed for major anions, cations, $\delta^{34} \mathrm{~S}_{-} \mathrm{SO}_{4}^{2-}, \delta^{18} \mathrm{O}_{-} \mathrm{SO}_{4}^{2-}$, and $\delta^{18} \mathrm{O}$ $\mathrm{H}_{2} \mathrm{O}$ (Item DR1).

\section{RESULTS AND DISCUSSION}

\section{Geochemical Evidence of Mineral Weathering}

Enrichment of sulfate $\left(\mathrm{SO}_{4}{ }^{2-}\right)$ in subglacial waters, relative to supraglacial waters, indicates pyrite weathering in the subglacial environment of RG (Table DR2; Item DR2). The $8^{34} \mathrm{~S}_{-} \mathrm{SO}_{4}{ }^{2-}$ and $\delta^{18} \mathrm{O}_{-} \mathrm{SO}_{4}^{2-}$ values in meltwaters also indicate pyrite oxidation (Table DR2; Item DR2). Our results are consistent with previous geochemical (Sharp et al., 1999; Tranter et al., 2002) and isotopic studies (Bottrell and Tranter, 2002; Wadham et al., 2004) of other glacial catchments that indicate a role for pyrite weathering in solute liberation, which has been argued to be the result of microbial activity. If microorganisms are driving pyrite weathering in RG subglacial sediments, then the microbial community would be expected to harbor $16 \mathrm{~S}$ rRNA genes affiliated with organisms capable of this physiological activity. Indeed, examination of microbial communities from RG (Hamilton et al., 2013) and from glacial catchments with geology similar to that of RG (Skidmore et al., 2005) reveals the presence of sequences affiliated with several organisms capable of oxidizing Fe and/or S.

\section{RG Subglacial Sediment Microbial Community Composition}

The majority of $16 \mathrm{~S}$ rRNA genes recovered from sediments sampled adjacent to the mineral coupon incubation site (Fig. 1; Table DR3,

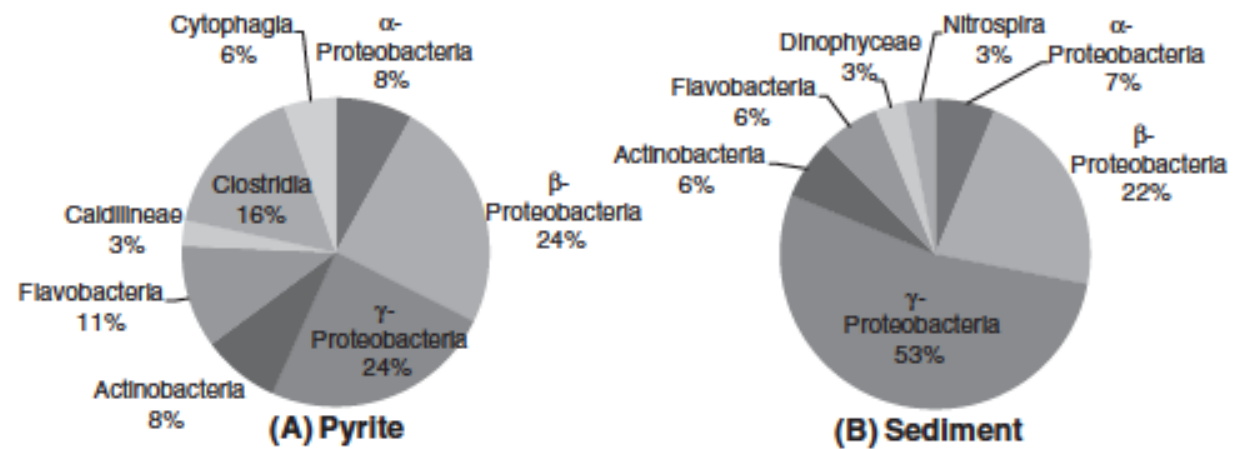

Figure 1. Phylogenetic aff liation of bacterial 16S rRNA genes in clone libraries. A: Generated from DNA extracted from pyrite. B: Generated from DNA extracted from Robertson Glacier sediment.

RG sediment), exhibited close affiliation with $\beta$ - and $\gamma$-Proteobacteria (e.g., Thiobacillus spp. [ $>94 \%$ identity], Acidithiobacillus ferrooxidans [90\% identity], and Siderooxidans lithoautotrophicus [96\% identity]). These organisms have been demonstrated to catalyze the oxidation of soluble and/or solid phase ferrous iron and sulfur in pure cultures (Karavaiko et al., 2003; Okereke and Stevens, 1991; Suzuki et al., 1990; Item DR2). $\beta$ - and $\gamma$-Proteobacteria are the dominant phylogenetic groups in nearly all subglacial systems investigated from alpine and polar environments (e.g., Foght et al., 2004; Skidmore et al., 2005), and all of these glaciers are underlain by bedrock that contains pyrite, similar to the bedrock at RG. Collectively, these observations suggest that pyrite weathering is an important process and is likely an important determinant in structuring the composition of microbial communities in this and other subglacial systems.

\section{Mineralogical Controls on Community Structure and Composition}

In order to further examine the role of pyrite and other minerals in structuring the composition of bacterial communities in the subglacial system, we compared 16S rRNA gene TRFLP profiles (each TRF considered a unique taxonomic unit) of bacterial communities associated with the coupon-incubated mineral surfaces to those associated with native sediments (RG sediment) using the Bray-Curtis (BC) similarity index. Such in-situ experiments represent a discrete colonization interval (7 months), and observations from such minerals may be confounded by differences in microbial colonization and successional dynamics. Notwithstanding, the bacterial community associated with the RG subglacial sediment is most similar to that associated with pyrite (BC index $=0.40$ ) (Fig. 2; Tables DR4 and DR5). This provides further evidence that pyrite has a strong influence on the composition and structure of bacterial communities in the subglacial environment at RG. The RG sediment bacterial community was also similar to the communities associated with the native rock from the RG catchment that was also incubated in the subglacial coupons, RG rock (BC index $=0.37$ ). For example, the RG sediment-associated bacterial community shared seven dominant phylotypes with the RG rockand pyrite-associated communities. Together these phylotypes accounted for $37.6 \%$ of the RG sediment-associated community, $70.9 \%$ of RG rock-associated community, and $53.4 \%$ of the pyrite-associated community (Table DR4). It is interesting that the communities associated with pyrite, RG rock, and RG sediment formed a cluster along with the community from RG water (subglacial meltwater containing suspended sediment and planktonic cells) (Fig. 2), further evincing the compositional similarity of these communities. These results, which demonstrate the similarity of communities on pyrite with those associated with native sediments, rocks, and water, are supported by

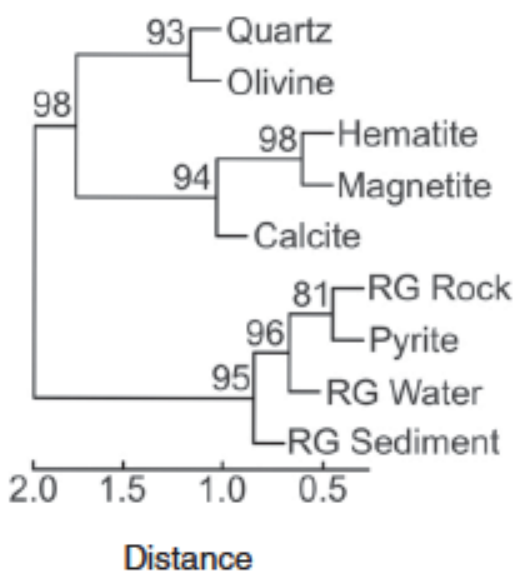

Figure 2. Hierarchical agglomerative clustering dendogram depicting Bray-Curtis similarity of bacterial 16S rRNA gene assemblages (Table DR4; see footnote 1) associated with mineral substrata, Robertson Glacier (RG) sediments, or RG meltwater. Data transformed to dendogram using Ward distance method. P-values supporting clustering at each node are depicted. 
sequence-based comparisons of community 16S rRNA genes that also reveal significant overlap in the phylogenetic composition of pyrite- and RG sediment-associated communities (Table DR3). Because pyrite is a constituent of RG rock ( $0.56 \mathrm{wt} \%)$, RG sediment (1.2 wt\%; Table DR1), and thus the suspended sediment in the RG water, these collective observations strongly suggest that pyrite, even in low concentrations, is a key control on the subglacial sediment-associated bacterial communities, perhaps due to a selective advantage to organisms that actively metabolize $\mathrm{Fe}$ and $\mathrm{S}$ in this mineral.

The other Fe-bearing minerals, hematite and magnetite, harbored microbial communities similar in structure and composition to each other ( $\mathrm{BC}$ index $=0.42$ ); this would be expected, considering that they are both $\mathrm{Fe}$ oxides. It is important that the bacterial communities associated with hematite and magnetite were also similar to the communities associated with the RG sediment (BC index $=0.26$ and 0.34 , respectively), though less than when compared with the pyrite-associated community (BC index $=0.40$ ) (Fig. 2; Table DR5). While XRD was unable to detect Fe-oxides in the RG bedrock (Table DR2), Fe-oxyhydroxides, which are derived from the oxidation of pyrite (e.g., Tranter et al., 2002), are likely to be present in the subglacial RG sediments. Moreover, direct measurements in other glacial environments indicate that $\mathrm{Fe}$-oxyhydroxides exist as single grain or aggregate nanoparticles and/or as labile surface coatings of other mainly silicate sediments (Mitchell et al., 2001; Raiswell et al., 2009). Thus Fe-oxyhydroxides in RG sediments may also influence microbial communities in subglacial environments, and account for the high similarity of hematite and magnetite communities to RG sediment communities. This hypothesis is further supported by the recovery of 16S rRNA gene clones from the RG sediment-associated library that are affiliated with Rhodoferax ferrireducens (Table DR3), an iron-reducing chemotroph (Finneran et al., 2003). Olivine, while containing $\mathrm{Fe}^{2+}$ at $7.5 \mathrm{wt} \%$
(Table DR2), harbored communities that shared little resemblance to RG rock and RG sediment communities, presumably because it was not detected in the catchment bedrock.

Communities associated with quartz and calcite exhibited low similarity to, and were distinct from, those communities associated with RG sediment, RG water, and RG rock (Fig. 2), despite their abundance in the catchment bedrock (Table DR1). This is presumably due to a lack of any potential metabolic substrate associated with the calcite or quartz mineral phases, aside from the potential use of calcite-derived carbonate as a source of carbon. Therefore TRFLP adds further evidence suggesting that Fe- and S-containing minerals, particularly pyrite, have a strong influence on the structure and composition of subglacial bacterial communities, presumably due the selective advantage afforded to those that metabolize these available substrates.

\section{Mineralogical Controls on Biomass}

We compared the quantity of genomic DNA extracted from the mineral phases as a proxy for assessing the amount of biomass that accumulated on the mineral surfaces, with the premise that higher biomass loadings might indicate that the populations are using the minerals as a substrate to support their metabolism. We hypothesized that minerals containing $\mathrm{Fe}$ and $S$, which can support the metabolism of a wide variety of microbial populations (Luttge et al., 2005; Shock, 2009), would harbor a higher biomass. Surface-associated biomass was particularly pronounced on Fe-bearing oxides and sulfides (hematite, magnetite, and pyrite; 204, 190 , and $83 \mathrm{ng} \mathrm{DNA} / \mathrm{g}$ mineral, respectively), but much lower on pyrite-containing RG rock and $\mathrm{Fe}$-bearing olivine $\left(\mathrm{Fo}_{90} \mathrm{Fa}_{10}\right)(25$ and $17 \mathrm{ng}$ DNA/g mineral, respectively) (Fig. 3). These differences are correlated with the abundance of $\mathrm{Fe}$ in the minerals and rocks, which was greatest in hematite (70 wt \%), magnetite (84 wt\%), and pyrite (47 wt\%), compared to only $7.5 \mathrm{wt} \%$ in olivine and $1.6 \mathrm{wt} \%$ in RG rock.
The lowest surface-associated biomass was recovered from calcite and quartz (17 and 16 ng DNA/g mineral, respectively); this may reflect the lack of any $\mathrm{Fe}$ or other abundant metabolic substrate in these carbonate and silicate minerals (Fig. 3).

These data demonstrate that the abundance of $\mathrm{Fe}$ in subglacial minerals influences the respective surface-associated biomass, suggesting that these populations are using $\mathrm{Fe}$ in the minerals to support their metabolism. Importantly, the valence state of Fe in these minerals is different (pyrite $2^{+}$, hematite $3^{+}$, magnetite $2^{+} / 3^{+}$), consistent with community $16 \mathrm{~S}$ rRNA gene compositions, which indicate the presence of populations putatively involved in $\mathrm{Fe}$ oxidation or reduction in the RG sediments (Table DR3). Similarly, the metabolism of S in pyrite is also likely to have a strong influence on surface-associated biomass, as evinced by pyrite-associated 16S rRNA gene sequences with a high similarity to microorganisms known to metabolize sulfur (Table DR3), but this cannot be comparatively quantified in the minerals used. Together with molecular-based data that indicate that pyrite and Fe-oxides harbor communities that are most similar to the RG sediments, this strongly suggests that (1) pyrite and its weathering products (i.e., Fe-oxyhydroxides, thiosulfate) strongly influence subglacial microbial communities due to their ability to transform and utilize the mineral phase through redox reactions, and (2) the Fe concentration of Fe-bearing minerals and rocks has a direct influence on surface-associated biomass in subglacial environments. Microbial interaction with mineral surfaces and the metabolism of key species such as $\mathrm{Fe}$ and $\mathrm{S}$ may therefore be critical mechanisms for sustaining life in subglacial systems at present, and over glacialinterglacial time scales. This is of global significance given that ice sheets covered $30 \%$ of Earth's continental land surface during Quaternary glaciations, and as much as $100 \%$ during pervasive low-latitude glaciations in the Neoproterozoic (Kirschvink, 1992).
Figure 3. A: Biomass (extractable DNA as proxy) associated with mineral substrata following 7 month colonization in subglacial stream. Error bars ref ect standard deviation of three replicate determinations of DNA concentration from pool of three replicate mineral extractions. B: Correlation between biomass and $\mathrm{Fe}$ content, as determined by energy-dispersive X-ray spectroscopy [olivine, Robertson Glacier (RG) rock, calcite, and quartz; error bars are smaller than symbols] or from pure phase stoichiometry (pyrite, hematite, and magnetite).

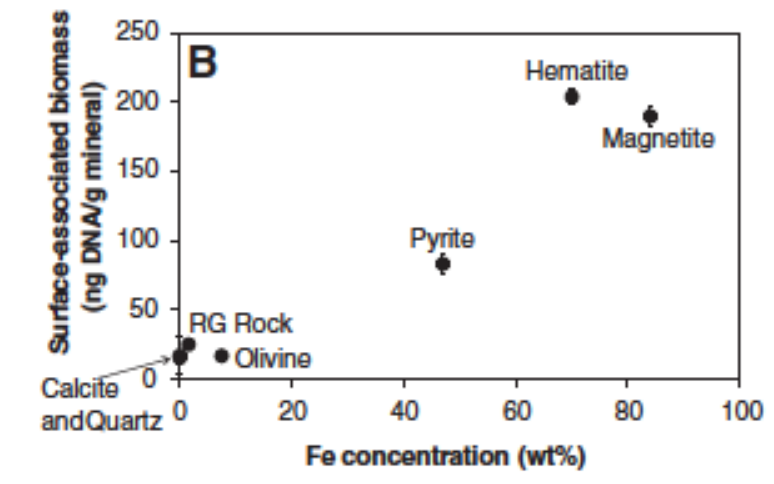

Mineral substratum

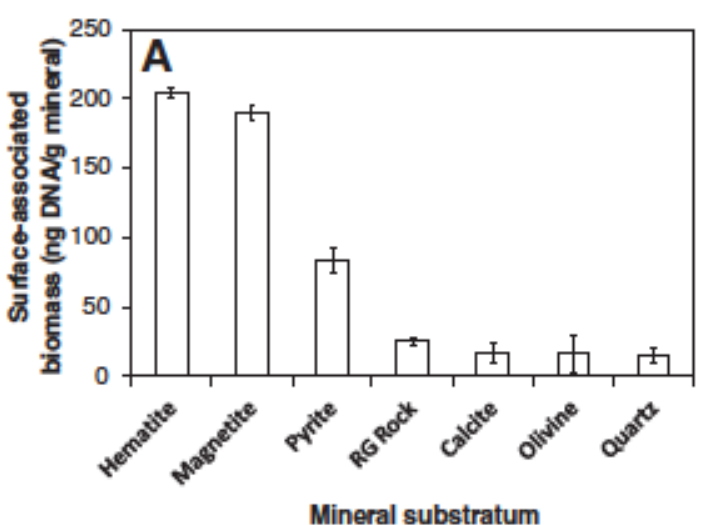




\section{CONCLUSION}

Previous studies have demonstrated the importance of particulate-associated microbes in subglacial environments and have indicated that this biomass represents a larger fraction of the community when compared with planktonic populations (e.g., Sharp et al., 1999; Skidmore et al., 2005). Our results indicate that mineralogy, due to the influence on community composition, structure, and abundance, may help to explain these previous observations. Specifically, pyrite is the dominant mineralogical control on subglacial community structure at Robertson Glacier, and mineral-associated biomass was proportional to the abundance of Fe in the incubated minerals. This suggests the importance of Fe and $\mathrm{S}$ metabolism at the mineral surface, as supported by the recovery of $16 \mathrm{~S}$ rRNA gene sequences that were closely affiliated with organisms that are known to metabolize these species. Solid-phase mineral utilization by microbial populations is likely a critical, life-sustaining strategy that has enabled subglacial ecosystems to persist during extended glacial-interglacial time scales, when ice masses covered between $30 \%$ and $100 \%$ of Earth's continental land surface.

\section{ACKNOWLEDGMENTS}

Mitchell and Boyd were supported by a grant from the NASA Montana Space Grant Consortium. Boyd acknowledges support from the NASA Astrobiology Institute (NAI) postdoctoral fellowship program. Boyd and Skidmore were supported by NASA grant NNX10AT31G. Energy-dispersive X-ray spectroscopy analysis was performed by Vernon Phoenix, University of Glasgow. Dave Mogk provided mineral specimens from the Montana State University mineral collection. We thank Biogeosciences Institute at University of Calgary's Kananaskis Field Station for use of field and laboratory facilities.

\section{REFERENCES CITED}

Bottrell, S.H., and Tranter, M., 2002, Sulphide oxidation under partially anoxic conditions at the bed of the Haut Glacier d'Arolla, Switzerland: Hydrological Processes, v. 16, p. 2363-2368, doi:10.1002/hyp.1012.

Boyd, E., Cummings, D., and Geesey, G., 2007, Mineralogy influences structure and diversity of bacterial communities associated with geological substrata in a pristine aquifer: Microbial Ecology, v. 54, p. 170-182, doi:10.1007 /s00248-006-9187-9.

Boyd, E.S., Skidmore, M., Mitchell, A.C., Bakermans, C., and Peters, J.W., 2010, Methanogenesis in subglacial sediments: Environmental Microbiology Reports, v. 2, p. 685-692, doi:10.1111/j.1758-2229.2010.00162.x.

Boyd, E.S., Lange, R.K., Mitchell, A.C., Havig, J.R., Hamilton, T.L., Lafrenière, M.J., Shock, E.L., Peters, J.W., and Skidmore, M., 2011, Diversity, abundance, and potential activity of nitrifying and nitrate-reducing microbial assemblages in a subglacial ecosystem: Applied and Environmental Microbiology, v. 77 , p. 4778-4787, doi:10.1128 /AEM.00376-11.

Brown, G.H., 2002, Glacier meltwater hydrochemistry: Applied Geochemistry, v. 17, p. 855-883, doi:10.1016/S0883-2927(01)00123-8.

Christner, B.C., 2002, Incorporation of DNA and protein precursors into macromolecules by bacteria at $-15^{\circ} \mathrm{C}$ : Applied and Environmental Microbiology, v. 68, p. 6435-6438, doi:10.1128 /AEM.68.12.6435-6438.2002.

Finneran, K.T., Johnsen, C.V., and Lovley, D.R., 2003, Rhodoferax ferrireducens sp. nov., a psychrotolerant, facultatively anaerobic bacterium that oxidizes acetate with the reduction of $\mathrm{Fe}$ (III): International Journal of Systematic and Evolutionary Microbiology, v. 53, p. 669-673, doi:10.1099/ijs.0.02298-0.

Foght, J., Aislabie, J., Turner, S., Brown, C.E., Ryburn, J., Saul, D.J., and Lawson, W., 2004, Culturable bacteria in subglacial sediments and ice from two Southern Hemisphere glaciers: Microbial Ecology, v. 47, p. $329-340$, doi:10.1007/s00248-003-1036-5.

Hamilton, T., Peters, J., Skidmore, M., and Boyd, E., 2013, Molecular evidence for an active endogenous microbiome beneath glacial ice: ISME Journal, v. 7, doi: 10.1038/ismej.2013.31.

Karavaiko, G.I., Turova, T.P., Kondrat'eva, T.F., Lysenko, A.M., Kolganova, T.V., Ageeva, S.N., Muntyan, L.N., and Pivovarova, T.A., 2003, Phylogenetic heterogeneity of the species Acidithiobacillus fermoxidans: International Joumal of Systematic and Evolutionary Microbiology, v. 53, p. 113-119, doi:10.1099/ijs.0.02319-0.

Kirschvink, J.L., 1992, Late Proterozoic low-latitude global glaciation: The snowball earth, in Schopf, J.W., et al., eds., The Proterozoic biosphere: A multidisciplinary study: Cambridge, UK, Cambridge University Press, p. 51-52.

Lanoil, B., Skidmore, M., Priscu, J.C., Han, S., Foo, W., Vogel, S.W., Tulaczyk, S., and Engelhardt, H., 2009, Bacteria beneath the West Antarctic Ice Sheet: Environmental Microbiology, v. 11, p. $609-615$, doi: $10.1111 /$ j.1462-2920.2008 $.01831 . x$.

Luttge, A., Zhang, L., and Nealson, K.H., 2005, Mineral surfaces and their implications for microbial attachment: Results from Monte Carlo simulations and direct surface observations: American Journal of Science, v. 305, p. 766790, doi:10.2475/ajs.305.6-8.766.

Mitchell, A., Brown, G.H., and Fuge, R., 2001, Minor and trace element export from a glacierized Alpine headwater catchment (Haut Glacier d'Arolla, Switzerland): Hydrological Processes, v. 15, p. 3499-3524, doi:10.1002/hyp.1041.

Montross, S.N., Skidmore, M., Tranter, M., Kivimäki, A.-L., and Parkes, R.J., 2013, A microbial driver of chemical weathering in glaciated systems: Geology, v. 41, p. $215-218$, doi: 10.1130 /G33572.1.

Okereke, A., and Stevens, S.E., Jr., 1991, Kinetics of iron oxidation by Thiobacillus ferroaxidans. Applied and Environmental Microbiology, v. 57, p. 1052-1056.
Raiswell, R., Benning, L.G., Davidson, L., Tranter, M., and Tulaczyk, S., 2009, Schwertmannite in wet, acid, and oxic microenvironments beneath polar and polythermal glaciers: Geology, v. 37, p. 431-434, doi:10.1130/G25350A.1.

Sharp, M., Parkes, J., Cragg, B., Fairchild, I.J., Lamb, H., and Tranter, M., 1999, Widespread bacterial populations at glacier beds and their relationship to rock weathering and carbon cycling: Geology, v. 27, p. 107-110, doi:10.1130/00917613(1999)027<0107:WBPAGB $>2.3 . C O ; 2$.

Sharp, M., Creaser, R.A., and Skidmore, M., 2002, Strontium isotope composition of runoff from a glaciated carbonate terrain: Geochimica et Cosmochimica Acta, v. 66, p. 595-614.

Shock, E.L., 2009, Minerals as energy sources for microorganisms: Economic Geology and the Bulletin of the Society of Economic Geologists, v. 104 , p. $1235-1248$, doi:10.2113/gsecongeo .104 .8 .1235 .

Skidmore, M.L., Foght, J.M., and Sharp, M.J., 2000, Microbial life beneath a high arctic glacier: Applied and Environmental Microbiology, v. 66, p. 3214-3220, doi:10.1128/AEM.66.8.3214 -3220.2000 .

Skidmore, M., Anderson, S.P., Sharp, M., Foght, J., and Lanoil, B.D., 2005, Comparison of microbial community compositions of two subglacial environments reveals a possible role for microbes in chemical weathering processes: Applied and Environmental Microbiology, v. 71, p. 6986-6997, doi:10.1128/AEM.71.11.6986 -6997.2005 .

Suzuki, I., Takeuchi, T.L., Yuthasastrakosol, T.D, and Oh, J.K., 1990, Ferrous iron and sulfur oxidation and ferric iron reduction activities of ThiobacilIus fermoaxidans are affected by growth on ferrous iron, sulfur, or a sulfide ore: Applied and Environmental Microbiology, v. 56, p. 1620 1626.

Tranter, M., Sharp, M.J., Lamb, H.R., Brown, G.H., Hubbard, B.P., and Willis, I.C., 2002, Geochemical weathering at the bed of Haut Glacier d'Arolla, Switzerland-A new model: Hydrological Processes, v. 16, p. 959-993, doi:10.1002 /hyp.309.

Tranter, M., Skidmore, M., and Wadham, J., 2005, Hydrological controls on microbial communities in subglacial environments: Hydrological Processes, v. 19, p. 995-998, doi:10.1002/hyp .5854 .

Wadham, J.L., Bottrell, S., Tranter, M., and Raiswell, R., 2004, Stable isotope evidence for microbial sulphate reduction at the bed of a polythermal high Arctic glacier: Earth and Planetary Science Letters, v. 219, p. 341-355, doi:10.1016 /S0012-821X(03)00683-6.

Wynn, P.M., Hodson, A.J., Heaton, T.H.E., and Chenery, S.R., 2007, Nitrate production beneath a High Arctic glacier, Svalbard: Chemical Geology, v. 244, p. 88-102, doi:10.1016/j chemgeo. 2007.06 .008 .

Manuscript received 2 November 2012

Revised manuscript received 14 March 2013

Manuscript accepted 19 March 2013

Printed in USA 